\title{
TOTAL EDUCATIONAL COSTS OF AN INTEGRATED NURSING CURRICULUM ${ }^{1}$
}

\author{
Maria Cristina Cescatto Bobroff ${ }^{2}$ \\ Pedro A. Gordan ${ }^{3}$ \\ Mara Lúcia Garanhani ${ }^{3}$
}

Bobroff MCC, Gordan PA, Garanhani ML. Total educational costs of an integrated nursing curriculum. Rev Latino-am Enfermagem 2009 janeiro-fevereiro; 17(1):14-20

\begin{abstract}
Innovative changes in undergraduate Nursing programs have brought about new methodologies and the need for cost evaluation. This study aims to develop a model for cost estimation, and to estimate educational costs of an integrated Nursing curriculum at a public university. This is a case study conducted in stages: model development, data collection, analysis and interpretation. The cost-construction model consisted of six steps: data collection; educational and support activity costs; four-year course educational costs; educational support costs; joint product costs and total educational costs. Findings showed a total educational cost per student/year US\$3,788.82. Course team faculty included 97 members. The cost analysis in faculty contact hours is the most appropriate cost unit as it most consistently reflects faculty time devoted to teaching. The knowledge about educational costs provided information that may be useful for a different approach to the integrated curriculum management, with a view to putting its educational objectives in practice.
\end{abstract}

DESCRIPTORS: curriculum; costs and cost analysis; education higher; education; nursing; faculty nursing; undergraduate course

\section{COSTOS EDUCACIONALES TOTALES DEL CURRÍCULO INTEGRADO DE ENFERMERÍA}

Para enfrentar los cambios innovadores en los cursos de Enfermería, fue necesario incorporar nuevas metodologías y evaluar los costos. Los objetivos de este estudio fueron construir un modelo y estimar los costos educativos del currículo integrado de Enfermería en una universidad pública, a través de la metodología de estudio de caso - construcción de modelo, recolección, análisis e interpretación de los datos. El modelo construido tuvo las siguientes etapas: recolección de datos, costos educativos por serie y costos de las actividades de apoyo, costos educativos de las cuatro series y de soportes educacionales, costos compartidos y costos educativos totales. Los resultados y la discusión muestran que el costo educacional total anual/alumno fue de US\$ 3.788,82. Participaron del curso 97 docentes. El análisis de costos en horas-contacto docente es la unidad de costo que proporciona el factor más consistente del tiempo docente utilizado con instrucción. Se concluye que el conocimiento de los costos educativos generó informaciones que pueden servir para la gestión del currículo integrado con la finalidad de hacer efectivos sus objetivos educacionales.

DESCRIPTORES: currículum; costos y análisis de costo; educación superior; educación en enfermería; docente de enfermería; graduación

\section{CUSTOS EDUCACIONAIS TOTAIS DE CURRÍCULO INTEGRADO DE ENFERMAGEM}

Face às inovadoras mudanças na graduação em Enfermagem, houve incorporação de novas metodologias e necessidade de avaliação dos custos. Os objetivos deste estudo foram construir modelo e estimar os custos educacionais de currículo integrado de Enfermagem em uma universidade pública, através de metodologia de estudo de caso - construção do modelo, coleta, análise e interpretação dos dados. O modelo construído constou das etapas: coleta de dados, custos educacionais por série e custos das atividades de apoio, custos educacionais das quatro séries e de suportes educacionais, custos compartilhados e custos educacionais totais. Pelos resultados e discussão vê-se que o custo educacional total anual/aluno foi de US\$3,788.82. Participaram do curso 97 docentes. A análise de custos em horas-contato docente é a unidade de custo que proporciona fator mais consistente do tempo docente gasto com instrução. Conclui-se que o conhecimento dos custos educacionais gerou informações que podem servir para a gestão do currículo integrado na efetivação de seus objetivos educacionais.

DESCRITORES: currículo; custos e análise de custo; educação superior; educação em Enfermagem; docente de Enfermagem; graduação

Universidade Estadual de Londrina, Brazil:

${ }^{1}$ Paper extracted from Doctoral Dissetation; ${ }^{2}$ RN, Ph.D. in Health Sciences, e-mail: cris.bobroff@hotmail.com; ${ }^{3}$ Associate Professor at Centro de Ciências da Saúde, Brasil, e-mail: gordan@sercomtel.com.br, maragara@dilk.com.br. 


\section{INTRODUCTION}

In 1994, the Brazilian Ministry of Education established the minimum levels for undergraduate Nursing curricula. Next, the Law of Guidelines and Bases for National Education, sanctioned in 1996, and the National Curriculum Guidelines for Nursing Programs in 2001 also guided curriculum changes to adjust to new social, political and economic population profiles and health system realities.

Different teaching approaches have been adopted in nursing undergraduate programs, but the costs of these approaches have been questioned, as they differ from the established traditional education model $^{(1-3)}$.

There is international research on nursing education costs ${ }^{(3-7)}$, but no studies have been conducted on nursing curriculum innovations in Brazil.

Background of curriculum changes in Brazil

Brazilian Nursing education was officially initiated by Decree no $16300 / 23$ in Rio de Janeiro. There were some curriculum changes in Nursing education in Brazil in 1923, 1949, 1962, and $1972^{(8)}$. Afterwards, from 1970 to 1985 there were great professional advances, backed by public health policies from the World Health Organization (WHO) and the Pan-American Health Organization $(\mathrm{PAHO})^{(9)}$.

In the 1980's, public health policies incorporated some concepts into education, such as equity, integrality and universality. At that time, a discussion started about the need to reform the 1972 curriculum, which was primarily hospital-centered ${ }^{(10)}$. This curriculum no longer met the demands of nursing education, and there was also a need for changes concerning primary health care.

The Brazilian Nursing Association had set out a professional movement proposing a new curriculum approach, which was sanctioned by government Decree no 1721/94. Education offered an opportunity for change while developing students' critical awareness and social commitment ${ }^{(11)}$.

A major curriculum approach that influenced education theory and Brazilian educators was social reconstruction, ${ }^{(12)}$ which adopts political emancipatory values to face social concerns and change reality.

In the 1990's, a professional organization was established in 11 Latin American countries to reorganize undergraduate health program education, called UNI projects. They brought a new approach to health provider education in Latin America. In Brazil, these projects supported the restructuring of Medicine and Nursing undergraduate program curricula, for instance at a state university in the state of Paraná, southern Brazil, from 1992 to $2000^{(13-14)}$.

At this same university, the Nursing program underwent its sixth curriculum change in 2000, to develop a so-called integrated curriculum. The university faculty members chose to "go beyond the structural curriculum reform, and to know and change educational practice"(14). This proposal, based on critical-social education concepts, broke with traditional teaching models ${ }^{(15)}$ and supported problembased principles. One of its goals was integration of faculty members and multidisciplinary work to improve students' learning. The model allows students to break their basic knowledge as they acquire the new content. This process requires time for faculty team to prepare learning activities, as well as extra time for faculty-student contact, so that the learning process can take place.

Undergraduate health schools undergoing these curriculum changes also met some challenges, such as incorporating new methodologies and evaluation models, integrating basic and clinical science faculty and contents and interdisciplinary practices within and outside school. Nursing graduates will have to respond to the challenges they will encounter in their real jobs.

New educational practices entail process changes and, probably, different costs. Cost estimation is a factor to be included in the analysis of changes already in place, but it cannot be considered individually. In addition to costs, the analysis of results and impact of curriculum changes should include other factors. Health education managers need to know the actual operating costs of these programs.

The Brazilian Ministries of Health and Education, as well as Curriculum Guidelines for Health programs, have undergone a change process and further curriculum reform requires an in-depth analysis of educational costs.

\section{OBJECTIVES}

The objective of the present study was to develop a cost estimation model, and to estimate the 
educational costs of an integrated Nursing program at a public university in the state of Paraná, Brazil.

\section{METHODS}

Prospective case study, carried out to estimate educational costs of a Nursing program.

A case study is the most comprehensive method in terms of data collection. Data can be collected from documentary analysis, interviews, personal reports and spontaneous observations, among others ${ }^{(16)}$.

The study comprised the following steps: cost model development, data collection, analysis and interpretation.

Some definitions were established for a better understanding of the concepts applied to this study, as follows:

Educator contact hour (ECH) - one $\mathrm{ECH}$ is a 50 -minute class when the educator was physically present, in direct contact with students, in clinical or theoretical teaching activities.

Educational costs - academic costs related to the teaching program and its support (faculty time devoted to directly related teaching activities).

Educational support costs (ESC) - faculty activity costs essential to education and teaching-learning competencies (administrative activities).

Joint product costs (JPC) - total joint or shared activity costs related to the teaching hospital.

Direct costs - costs directly related to the teaching program; the faculty working hours devoted to teaching in educator contact hours.

Indirect costs - teaching costs that support teaching activities (e.g., administrative staff costs, supplies, equipments, material depreciation, etc.).

\section{Cost-construction model}

The cost model constructed for data collection and estimation of the Nursing Program educational costs was based on the Cost Analysis and Construction Program $(P C A C)^{(17)}$. Teaching costs, joint product costs and total educational cost parameters and definitions ${ }^{(1)}$ were also included. The educational program costs are constructed by curriculum analysis and calculating the $\mathrm{ECH}^{*}$ required to maintain it ${ }^{(1)}$.

The total educational cost estimate model for a Nursing program ${ }^{* *}$ consists of six steps, as described below.

Data collection and analysis

$1^{\text {st }}$ step - Data collection from records and interviews: data were collected by the main investigator in 2005, 2006 and beginning of 2007. Cost analysis was made in reais and American dollars $^{* * *}$.

a. Documentary analysis: university records relevant to identify cost areas were analyzed before constructing the model and during data collection and analysis.

b. Interviews: A structured questionnaire was developed by the main investigator for carrying out semi-structured interviews with 52 individuals ${ }^{* * * *}$ about their ECHs. The number of meetings for the interviews was guided by the length and complexity of each course. Data validation was performed by showing them to at least one faculty member of each course and ECH data were showed to the interviewed faculty coordinators for final validation.

$2^{\text {nd }}$ step - Educational costs by year and support activity costs: ECHs of each year were calculated according to the faculty members' salaries in the program and supporting and basic activity costs, which together totaled direct and indirect costs and the total month/year student costs.

$3^{\text {rd }}$ step - Four-year educational costs: based on the costs obtained for each year in the $2^{\text {nd }}$ step, the total for a four-year program was calculated by summing them.

$4^{\text {th }}$ step - Educational support costs (ESC): direct costs for preparation and management of educational activities by the faculty member (headship, commission and coordination of each of the 16 teaching courses and undergraduate teaching projects).

\footnotetext{
${ }^{*} \mathrm{ECH}$ - one educator contact hour is equal to one educator-student contact teaching hour.

${ }^{* *}$ In the described model, the steps are independent for data collection and co-dependent for data estimation, as developed by Bobroff, 2008.

* Reais (R\$) is the Brazilian currency. For the conversion into American dollars, the 2005 "average yearly dollar rate" was used (US\$2.9305). Data were obtained from the Planning and Administrative Developing Management of the Dean's Office at the university where the Nursing Program under analysis is offered.

**** Subjects to be interviewed were selected from a convenience sample, according to the positions they held at the university. Course coordinators and at least one faculty member from each course and the Planning and Administrative Director from the Dean's Office were interviewed.
} 
$5^{\text {th }}$ step - Joint product costs from university hospital $\left(J P C^{*}\right)$ : indirect costs of support activity for the final product (university hospital costs in $\mathrm{R} \$$ and US\$ for education).

$6^{\text {th }}$ step - Total educational costs (TEC): the sum of $3^{\text {rd }}, 4^{\text {th }}$ and $5^{\text {th }}$ steps, estimating the monthly, yearly and total undergraduate education costs per student in $\mathrm{R} \$$ and US\$.

The study was approved by the hospital's Research Ethics Committee, Process number CEP 253/ 04, and all subjects signed a free and informed consent form.

\section{RESULTS AND DISCUSSION}

The results and discussion are presented together. Relevant aspects regarding estimated costs of the integrated curriculum are discussed here.

PCAC ${ }^{(17)}$ was developed for cost analysis of Medicine programs in Canada. It was based on a costconstruction model used by the US Institute of Medicine (IOM) in 1974 to estimate eight health education programs, including Nursing. This study was criticized because of its small sample size, representative of less than $3 \%$ of US Nursing schools ${ }^{(18)}$

Studies on the nursing area ${ }^{(3-7)}$ have failed to provide useful cost models and, thus, a new model had to be developed and adjusted for the present research.

In the PCAC ${ }^{(17)}$ and the cost model presented here, direct costs related to undergraduate programs were collected in $\mathrm{ECHs}$.

Educational program cost evaluation is complex ${ }^{(5)}$. Researchers often do not make careful cost comparisons between countries and institutions in the same country ${ }^{(19)}$. Comparisons can be made only if the same methods were applied in the cost analyses $^{(19)}$. Besides, particularities of each institution and teaching program should be taken into consideration to allow for a comparison. The study results could not be compared with those of other studies, as no studies with the same cost methodology were found in the literature. Other authors' comments and research results were included to support the study results.
Four-year educational costs

Teaching costs were described for the Medical area $^{(1)}$ and, here, they are called educational costs related and limited to the undergraduate program analyzed.

The four-year educational costs are presented in Table 1.

Table 1 - Distribution of educator contact hour, total cost by year (R\$ and US\$)

\begin{tabular}{ccccccc}
\hline Year & ECHs & $\%$ & $\mathbf{C} / \mathbf{H}$ & $\%$ & $\mathbf{R} \$$ & US $\$$ \\
\hline $1^{\text {st }}$ & 3,641 & 11.57 & 1,090 & 24.51 & $162,253.23$ & $55,367.08$ \\
$2^{\text {nd }}$ & 6,215 & 19.75 & 1,020 & 22.93 & $222,756.61$ & $76,013.17$ \\
$3^{\text {rd }}$ & 8,784 & 27.92 & 953 & 21.43 & $273,229.82$ & $93,236.59$ \\
$4^{\text {th }}$ & 12,818 & 40.74 & 1,384 & 31.12 & $506,460.15$ & $172,823.80$ \\
Total $^{\text {tal }}$ & 31,458 & 100.00 & 4,447 & 100.00 & $1,164,699.81$ & $397,440.64$ \\
\hline
\end{tabular}

Legend: $\mathrm{C} / \mathrm{H}$ - course hours per year ECHs - educator contact hours

Table 1 shows that there has been a linear increase in $\mathrm{ECHs}$ and costs from the $1^{\text {st }}$ to the $4^{\text {th }}$ years. A lower number of ECHs in the $1^{\text {st }}$ year can be explained by the fact that students were first approaching real professional activities, at a $1: 10$, $1: 20$ and 1:30 educator/student ratio during clinical practices. Higher ratios were reported in a study conducted in Central Africa, where they found 1:60 for classroom activities in the $1^{\text {st }}$ and $2^{\text {nd }}$ years and between $1: 10$ and $1: 15$ for clinical contact ${ }^{(6)}$.

Costs and ECHs gradually increased in the $2^{\text {nd }}$ and $3^{\text {rd }}$ years because of decreasing educator/ student ratios during clinical activities, $1: 5$ and $1: 6$ on average, due to the increasing complexity of activities performed by students in clinical sites. The average educator/student ratio in clinical sites reported in nursing education studies was $1: 6^{(7)}$ in the US and $1: 11^{(6)}$ in Central Africa.

Nursing program costs increase due to the need for a low educator/student ratio, as more faculty members are needed for clinical supervising.

Educator/student ratio was the specific variable that affected Nursing education costs in the IOM study ${ }^{(4)}$. It is also known that faculty jobs account for the highest costs in colleges ${ }^{(3)}$ and health-related courses require more faculty

* Data were collected from the Planning and Administrative Developing Management of the Dean's Office at the university and proportionally weighted: 1.0 for Medicine, 0.75 for Nursing, 0.5 for Pharmacy and 0.5 for Physical Therapy. 
members for clinical practice, when students are learning how to deliver care to people and have direct contact with patients on constant faculty supervision.

A major factor accounting for increased ECHs in the $4^{\text {th }}$ year was final paper advice $(34.56 \%)$. The remaining $\mathrm{ECHs}$ in the $4^{\text {th }}$ year were related to hospital area practices in the $1^{\text {st }}$ semester $(30.86 \%)$ and Nursing internship in the $2^{\text {nd }}$ semester (34.56\%).

Faculty participation in educator contact hour

Ninety-seven faculty members were involved in teaching activities in the Nursing undergraduate program and 87 of them had master's or doctorate degrees. The majority of the master's degrees were in Community Health (13) and Nursing (32) and most of the doctoral degrees were in Basic Sciences (20).

Table 2 - Distribution of mean $\mathrm{ECHs}$ and related standard deviation

\begin{tabular}{lccc}
\hline \multicolumn{1}{c}{$\begin{array}{c}\text { Areas I } \\
\text { departments }\end{array}$} & $\begin{array}{c}\text { Number of } \\
\text { faculty } \\
\text { members }\end{array}$ & $\begin{array}{c}\text { Mean (yearly } \\
\text { ECHs) }\end{array}$ & $\begin{array}{c}\text { Standard } \\
\text { deviation }\end{array}$ \\
\hline $\begin{array}{l}\text { Basic Science } \\
\text { Departments }\end{array}$ & 28 & 47 & 49 \\
$\begin{array}{l}\text { Community Health } \\
\text { Departments }\end{array}$ & 20 & 213 & 217 \\
$\begin{array}{l}\text { Nursing } \\
\text { Departments }\end{array}$ & 47 & 550 & 187 \\
\hline
\end{tabular}

Table 2 shows that many faculty members from Basic Sciences and Community Health Departments devoted fewer hours to the Nursing program in 2005. On the other hand, there was a more equal distribution of teaching hours among the Nursing Department undergraduate faculty members.

This distinct involvement of departments may reveal inadequate integration between faculty, areas and contents. It may also imply that, in this new reality, some faculty members had to adjust and have become "subspecialists" to fill the gaps left by other specialists who did not breakwith the traditional teaching model and were not able to process the new teaching and methodological approach. These data may provide input for further discussion between those responsible for putting the new curriculum into practice.

Educational costs and educational support costs

Student/year costs, including ECHs and support activities, were US\$1,662.92; when adding educational support costs the total cost was US\$ $1,765.27$. Therefore, a minor increase in student costs was observed.

University hospital joint product costs

There is no standard formula or ideal model to address educational costs and more specifically the joint product costs - JPC -, i.e. patient care, clinical teaching and research ${ }^{(1,5)}$. Hence, joint activities were considered in a shared manner and each activity had the same weight.

The university hospital joint costs, proportionally distributed in equal shares in the Nursing program and added to educational costs, totaled US\$3,686.48. These costs increased total undergraduate program costs.

Total educational costs

The historical Nursing program data from the university ${ }^{*}$ show that mean student/year cost lowered in 2005. However, currency exchange rate variations should be considered, as well as other factors for lowering costs, such as state government policies to reduce costs, among others. Providing integrated and traditional curricula at the same time may also have led to increasing costs in 2000 and 2001.

Costs presented in this step comprise undergraduate $\mathrm{ECHs}$ (direct costs) and related indirect costs.ctivities were only considered if measurable and exclusive to the undergraduate program.

A limitation of the present study was that costs related to intangible activities were left unmeasured ${ }^{(20)}$. These costs cannot be accurately measured and are associated to daily faculty activities such as course preparation, refresher courses, evaluations of course assignments, faculty meetings among others ${ }^{(20)}$. Further studies are needed to assess intangible costs.

* Data collected from the Planning and Administrative Developing Management of the Dean's Office at the university showed a Nursing program cost of US\$ $5,003.59$ in 2003 and US\$ 5,331.76 in 2004. 


\section{CONCLUSION}

When it was decided to estimate integrated curriculum costs, the authors' main concern was to find an adjustable cost estimate method. The PCAC ${ }^{(17)}$ described and applied in Medical education, proved to be a feasible method.

Another concern was that cost estimates could be used for diagnosis and evaluation of the implementation of innovative curriculum approaches. Costs should be one of the many components assessed while evaluating the feasibility of a new approach.

Moreover, the constructed model, so-called Total Educational Cost Estimate Model for a Nursing Program (MECEE) ${ }^{(20)}$, provided input on faculty course hours distribution, ECHs carried out throughout the school year, and different faculty and departments' involvement in the program's activities.

Besides gaining knowledge on undergraduate costs, the model has also provided some evidence about the performance of the integrated curriculum.

- The two departments most involved in faculty activities in the Nursing program were the Nursing and Community Health Departments.

- The Nursing Department focused on student contact activities in the undergraduate program, which increased linearly from the $1^{\text {st }}$ to $4^{\text {th }}$ year. But the same was not seen in other areas, such as Community Health and Basic Sciences.

- There has been a remarkably different involvement between faculty from Nursing and Community Health and from basic areas, raising a concern about the integration between the various areas of knowledge.

It is notable that, despite its relevance for teaching, university hospital joint product costs substantially increased Nursing undergraduate education costs.

The findings of the present study may help the program faculty to discuss and review criteria for better distribution of course hours and $\mathrm{ECH}$, and more adequate and balanced involvement of specialists from different areas in the program courses.

Knowledge on undergraduate educational costs can contribute to improve the management of an integrated curriculum through a different approach.

It is suggested that $\operatorname{MECEE}^{(20)}$ should be the standard model, as it has proved to be consistent and practical for estimating educational costs of Nursing and other health-related programs. The approach studied took into consideration educational program characteristics and proved to be complete and systematic. Further studies should be conducted to explore the relevance and efficacy of this cost model.

\section{REFERENCES}

1. Jones RF, Korn D. On the cost of educating a medical student. Acad Med 1997; 72(3): 200-10.

2. Nandi PL, Chan JNF, Chan CPK, Chan P, Chan LPK. Undergraduate medical education: comparison of problembased learning and conventional teaching. HKMJ. 2000; 6(3): 301-6.

3. Starck PL. The cost of doing business in nursing education. J Prof Nurs 2005;21:183-90.

4. Brown EL. Comparing and analyzing expenditure factors in nursing education. In: National League for Nursing, editor. Analyzing the cost of baccalaureate nursing education. New York (NY): NLN; 1982. p. 13-27.

5. Kummer K, Bednash G, Redman B. Cost model for baccalaureate nursing education. J Prof Nurs 1987; 176-85. 6. Namate DE. The cost of registered nurse-midwifery education in Malawi. J Advanced Nurs 1995; 22: 410-5.

7. Barton A, Moritz P, Griffin J, Smith M, Magilvy K, Preheim G, et al. A model to identify direct costs of nursing education: the Colorado Experience. Nurs Leadersh 2005; 9:155-62. 8. Ito EE, Peres AM, Takahashi RT, Leite MMJ. O ensino de enfermagem $e$ as diretrizes curriculares nacionais: utopia $x$ realidade. Rev ESC Enferm USP 2006; 40(4):570-5.

9. Villalobos MMD. Concepciones de la formación del enfermero. In: Sena RR de, editora. Educación de enfermería en América Latina. Bogotá: REAL, Universidad Nacional; 2000. p.81-91.

10. Clapis MJ, Nogueira MS, Mello DF, Corrêa AK, Souza MCBM, Mendes MMR. O ensino de graduação na Escola de Enfermagem de Ribeirão Preto da Universidade de São Paulo ao longo dos seus 50 anos (1953-2003). Rev Latino-am Enfermagem 2004 janeiro-fevereiro; 12(1):7-13.

11. Lima MADS. Ensino de enfermagem: retrospectiva, situação atual e perspectivas. Rev Bras Enferm 1994; $47(3): 270-7$

12. Vendrúsculo DMS, Manzolli MC. O currículo na e da enfermagem: por onde começar e recomeçar. Rev Latino-am. 
Enfermagem 1996 janeiro; 4(1):55-70.

13. Almeida MJ. Educação médica e saúde: possibilidades de mudança. Londrina (PR): Ed. UEL; Rio de Janeiro: ABEM; 1999.

14. Garanhani ML. Habitando o mundo da educação em um currículo integrado de enfermagem: um olhar à luz de Heidegger [tese]. Ribeirão Preto (SP): Escola de Enfermagem de Ribeirão Preto/USP; 2004.

15. Godoy CB. O curso de enfermagem da Universidade Estadual de Londrina na construção de uma nova proposta pedagógica. Rev Latino-am enfermagem 2002 julho-agosto; $10(4): 596-603$.
16. Gil AC. Como elaborar projetos de pesquisa. $4^{a}$ ed. São Paulo (SP): Atlas; 2006.

17. Valberg LS, Gonyea MA, Meredith A, Sinclair DG, Wade J. Planning the future academic medical center. CMAJ 1994 December; 151(11):1581-7.

18. Schilling JS. Studying the costs of nursing education: seven decades of effort. Nurs Health Care 1987;8:575-80. 19. Amaral NC. Evolução do custo do aluno das IFES: eficiência? Avaliação 2004; 9(2):115-26.

20. Bobroff MCC. Estimativa de custos educacionais totais currículo integrado do curso de enfermagem da UEL [tese]. Londrina (PR): Universidade Estadual de Londrina; 2008. 